\title{
Perceptions of Teachers and Students of the Promotion of Interaction Through Task-Based Activities in CLIL
}

\author{
VÍCTOR PAVÓN VÁZQUEZ \\ Marta Prieto Molina \\ FCO. JAVIER Ávila LÓPEZ \\ University of Córdoba (Spain)
}

Received: 21 March 2014 / Accepted: 17 May 2014

ISSN: $1697-7467$

\begin{abstract}
Task-based learning is a methodological strategy which can be of use in the integrated learning of language and subject matter, and its appropriateness for CLIL has been reported in different contexts (Cendoya \& di Bin, 2010; Escobar \& Sánchez, 2009; Poisel, 2012; Tardieu \& Doltisky, 2012). This study investigates the perceptions that teachers and students have of the use of task-based learning as an instrument to favour participation and interaction in CLIL. Particularly, the objective is to analyse these areas in a special context, with students exhibiting a low linguistic proficiency in a language school specifically oriented to the application of CLIL.

Keywords: CLIL, task-based approach, interaction, cooperative learning, communicative competences, language school.
\end{abstract}

La visión del profesorado y alumnado sobre el uso de la interacción mediante el uso de tareas en AICLE

RESUMEN: La enseñanza por tareas constituye una herramienta pedagógica adecuada para la enseñanza integrada de lengua y contenidos (AICLE), y su efectividad ha sido demostrada en diferentes contextos (Cendoya y di Bin, 2010; Escobar y Sánchez, 2009; Poisel, 2012; Tardieu y Doltisky, 2012). Este estudio se propone investigar las opiniones de profesores y alumnos sobre la relación entre la enseñanza por tareas y el fomento de la participación y la interacción en AICLE. Su objetivo es analizar estas áreas en un contexto diferente, un centro de idiomas, y con alumnos con una capacidad comunicativa no ideal en la lengua extranjera.

Palabras clave: AICLE, aprendizaje por tareas, interacción, aprendizaje cooperativo, competencia comunicativa, centro de idiomas.

\section{INTRODUCTION}

From 1995 to the present, European programmes and educational legislative actions have resulted in bilingual programmes being further established in education (Eurydice, 
2006:8; Marsh, 2013:17). In this new scenario, CLIL offers the possibility to use and learn the language in a natural and innovative way (Berton, 2008:143; Wolff, 2012:108), which has a direct impact in language learning (Llinares, Morton, Whittaker, 2012:53). In order to weigh the efficiency of models, methodologies and strategies in CLIL, it is convenient, together with the analysis of the structure of tasks and of interaction, to gain an insight into the students' and teachers' perceptions (Bonnet, 2012b:87). This study proposes to examine if the task-based approach within a specific CLIL teaching context will influence the development of the learner's communicative skills, and foster the learning of the language through interaction and the use of motivating tasks. Teachers' and students' perceptions are analysed to determine if task-based learning helps increase the students' interests towards linguistic competences and, thus, if it can strengthen the students' communicative skills.

\section{Theoretical FrameWORK}

\subsection{Task-based approach in CLIL}

Teaching a foreign language by using tasks came into fashion in the last decades of the $20^{\text {th }}$ Century within the paradigm of communicative language teaching (Brown, 1994; Richards and Rodgers, 1986), as a way to develop realistic communication in class (Carless, 2004; Ryba, 1992; Willis and Willis, 2007). The Common European Framework of Reference for Languages (CEFRL) defines a task as "a purposeful action to achieve a given objective" (Council of Europe, 2001:10), a task being then an activity in which the language is used for a communicative purpose "to accomplish an outcome" (Candlin and Murphy, 1987:10; Willis, 1996:23). According to Ellis (2003:9), tasks involve focusing on meaning, real-world language use, utilisation of the four language skills, and activation of cognitive processes. Nunan (1989:10) adds that working with tasks implies paying specific attention to the meaning rather than to the form. Consequently, the understanding of language input and the production of language input through interactions in real-life situations results in a better achievement of the communicative goals (Van den Branden, 2006:4).

CLIL is an approach which entails that the learning of content and the learning of the language occur in a simultaneous way (Coyle, Hood, Marsh, 2010:1; García, 2009:210; Marsh, 2002:15). And within this context, task-based learning becomes a desirable proposal for teaching content and language in an integrated way (Pérez, 2012), and proffers the adequate pedagogical framework and measures to cope with the cognitive and linguistic demands required. Teaching content through a foreign language "helps improve general education programmes" (Baetens Beardsmore, 2001:10) and contributes to the amelioration of a number of relevant aspects: for example, the increase in the students' language proficiency (Brevick and Moe, 2012; Lasagabaster, 2008); cognitive development (Lorenzo et al., 2009; Mondt, et al., 2011; Viebrock, 2012); and the development of the psycho affective dimension and intercultural learning (Marsh, 2007; Pena and Porto, 2008; D'Angelo and García Pascual, 2012; Méndez García, 2013). However, there are voices warning that maybe it is not so clear that learners learn as much content and language as it is claimed by Bonnet (2012a:66). Others affirm that the non-existence of fixed CLIL models nullifies the purported effectiveness of this model (Cenoz, Genesee and Gorter, 2013; Doyle, 2013), 
or even that the gains may be the result of social status and self-selection rather than the effect of CLIL (Bruton, 2011, 2013).

After considering this criticism it seems obvious that there is a need to gain insight into what is really going on in CLIL contexts, as suggested by Pérez Cañado (2012:329), or, as in the case of this study, of the beliefs, attitudes and behaviours of teachers and students with respect to its implementation. According to Berton (2008:146), task-based learning fits perfectly with the educational paradigm proposed by CLIL as "the understanding and assimilation of content matter is realised through the foreign language2. Also: "CLIL can transform classroom dynamics into one which is learner-centred, constructivist and motivating" (Ting, 2010:14). Consequently, Meyer (2010:19) defines the combination of CLIL and task-basedlearning as "symbiotic", since the obligatory use of authentic and meaningful content in the CLIL class goes hand in hand with the fulfilment of motivating and challenging tasks.

\subsection{Interaction and collaboration through task-based activities}

As stated in Long's Interaction Hypothesis (Long, 1996), fostering interaction is a necessary condition for the development of the language in second language acquisition because "it provides learners with the input they need" (Mackey, 1999:558). The same can be said for the CLIL classroom, as CLIL makes available opportunities for interaction that are not typical in traditional foreign language teaching (Dalton-Puffer, Nikula, and Smit, 2010:279). In CLIL the use of interaction and participation is one of the main drivers for success (Coonan, 2012) and it entails bringing into play cooperative learning (Casal, 2008), scaffolding to promote cognitive fluency (Meyer, 2010), and learning skills development (Mehisto, 2012). CLIL and task-based learning entail a potentially positive combination: "A lot of what goes on in the CLIL classroom involves practical application of knowledge through problem solving tasks and cooperative learning" (Pavón and Ellison, 2013:71); and "Student interaction and output are triggered by tasks which is why task design is at the heart of every CLIL lesson" (Meyer, 2010:17). Accordingly, one of the teachers' objectives in a CLIL class will be to design tasks that truly engage students' participation and interaction (Escobar and Sánchez, 2008:68).

Specific attention to the development of interaction falls into the paradigm of socioconstructivism and cooperative learning, where the students not only learn from their teachers but also from the other students (Pastor, 2011:112). In general, research has shown that cooperative learning contributes to the overall effectiveness of CLIL (Della Puppa, 2008; Guazzieri, 2008). Students feel encouraged to actively participate in the resolution of tasks starting with their already existing linguistic capacities, which makes them more confident (Poisel, 2012:261) and stimulates their self-esteem (Toscano, 2011:138). The fact that learners interact with each other allows them to share information and favours group cohesion (Dörnyei, 1997:485), which results in a more comfortable interaction context and, ultimately, enhances students' motivation. Students who play an active role in the development of cooperative activities are more willing to use the foreign language and, in general, to learn (Berton, 2008:149). Coonan (2012:63-64) reported that they find the use of the foreign language in CLIL more enjoyable and interesting, and that students experience a noticeable increase in their intrinsic and extrinsic motivation, and in their self-concept. 


\section{RESEARCH METHOD}

\subsection{Objectives}

This study investigates the use of task-based learning as a strategy to promote participation in the CLIL class. The general objective is to analyse the perceptions of teachers and students of the use of task-based learning to foster interaction and cooperative learning. As specific objectives, we attempt to evaluate their experience and opinions with the following research questions:

a) Is working with tasks perceived as having a positive effect on the strengthening of the students' linguistic skills?

b) Which are the most effective strategies to promote interaction?

c) What is the influence of task-based learning on students' motivation?

\subsection{Context and participants}

The language school where the study was conducted is a School of English specifically oriented to CLIL, "The Globe CLIL Centre" in Córdoba (Spain). The school offers additional language classes to students receiving mainstream education in Spanish, but in a different way to traditional language schools, since English is learnt and used while learning history, science and arts. The sample consisted of 34 students (mother tongue, Spanish), from three different levels: pupils of the Basic 2 Initial level, corresponding to an A1 level according to the CEFR; students of the Beginner Initial level, equivalent to an A2.1; and students of the Elementary level, equitable to an A2.2 level. Students were divided according to level and not to age, age of participants ranged from 8-10 years. The sample was selected consciously to see the effect of CLIL with students exhibiting a low proficiency in English. With regard to the teachers participating, 6 teachers (all of them permanent teachers of the researched group with a Master's Degree in bilingual education and CLIL, and with 1-2 years of experience) answered the questionnaire specifically designed to measure their attitudes and beliefs regarding professional roles and responsibilities.

\subsection{Procedure and data gathering}

The investigation was carried out without interrupting the usual instruction schedule. Data collection was done through questionnaires designed to evaluate students' interaction and linguistic skills, and teachers' roles, bearing in mind the research questions posited. Both questionnaires for teachers and students consisted of closed-ended questions, and had been previously sent for validation to a number of experts in the fields of task-based learning, collaborative learning and CLIL. There were 35 questionnaires in total in the teachers' survey and 21 in the students'. The questionnaires for the students were administered in their first language to guarantee understanding (see appendices 1 and 2 for the questionnaires). Anonymity and confidentiality were ensured during administration of the questionnaires and report writing. 


\subsection{Results}

Figures 1 and 2 feature the results from the students' questionnaire, and Figures 3 and 4 show the results from the teachers' questionnaires.

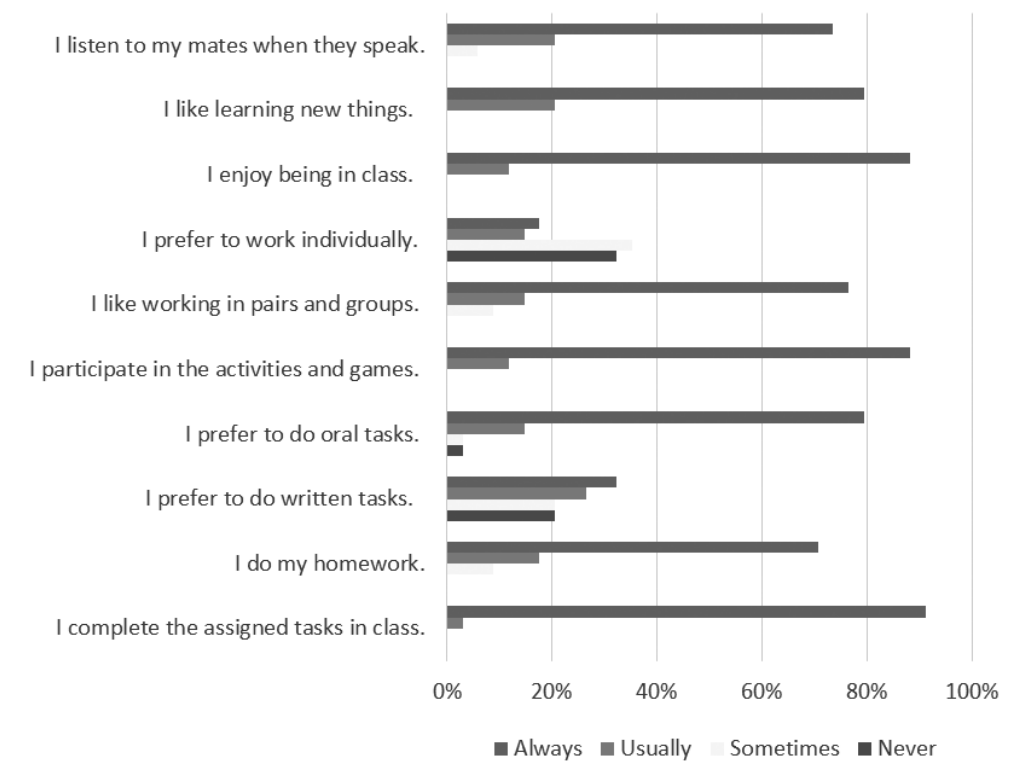

Figure 1: General involvement of students

Figure 1 shows results regarding the general involvement of students in doing their tasks. As it can be seen, the majority of students $(88,2 \%)$ frequently participated in the different types of activities proposed. The majority of the students actively participate in class, and the involvement in the attainment of the different tasks indicates that they are engaged in their own learning process and that their motivation is high. The only area in which a low percentage of students acknowledge they do not always participate in class is in the attainment of written tasks $(41,2 \%: 20,6 \%$ never $+20,6 \%$ sometimes $)$. The preference for participating in oral tasks is significant $(94,1 \%: 14,7 \%$ usually $+79,4 \%$ always), given that their low proficiency level would lead one to expect that they would not be willing to speak in class.

Regarding students' willingness to interact with their peers and the existence of a comfortable atmosphere when working in pairs/groups or individually, putting together the 'usually' and 'always' dimensions', students prefer to work in pairs and groups $(76,5 \%)$ rather than individually $(32,4 \%)$, which denotes a preference for collaboration and interaction with others in the construction of meaning. Most students listen to their classmates when they speak $(73,5 \%)$, proof that they feel engaged in the fulfilment of the tasks. Additionally, a large majority enjoy being in class $(85,3 \%)$ and like learning new things $(79,4 \%)$, results that suggest that they feel comfortable when using the foreign language to access information and to communicate with the other students. 


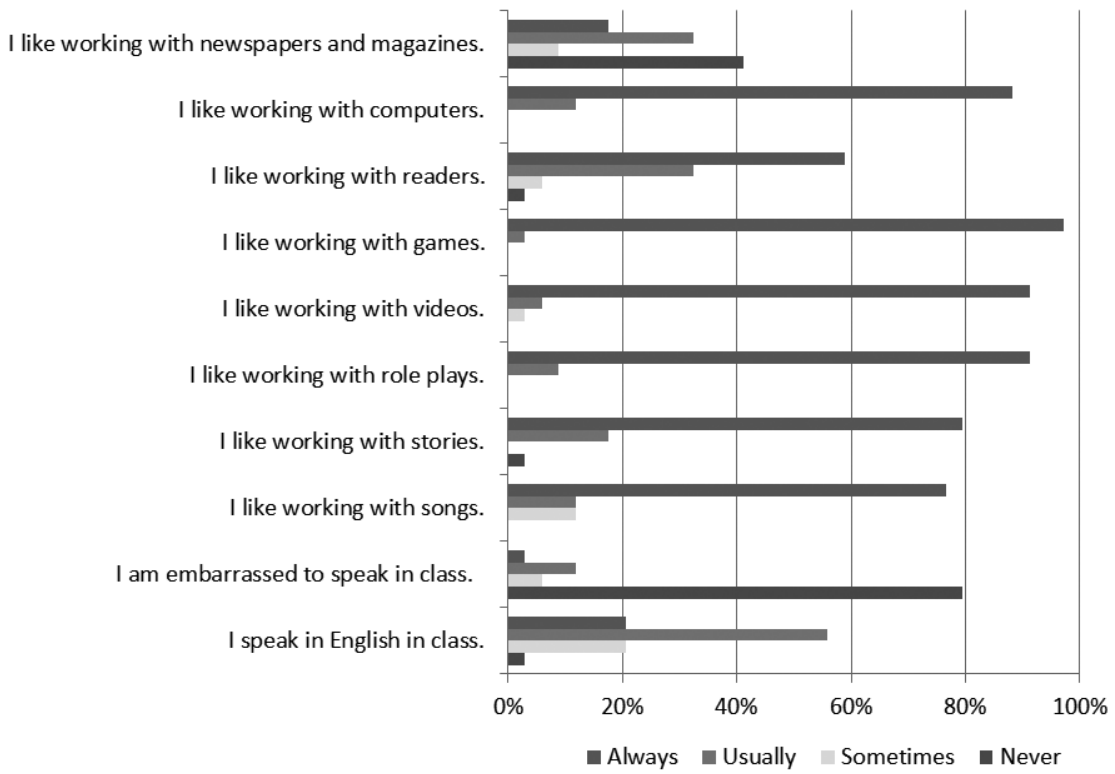

Figure 2: Use of the FL

Concerning the use of the foreign language and the possible embarrassment this entails, most students $(76,5 \%)$ answered they usually $(55,9 \%)$ or always $(20,6 \%)$ speak English in class, and only a few of them never use this language (2,9\%). With respect to their feelings when using English, the majority are never embarrassed to speak English in class $(79,4 \%)$, with $5,9 \%$ asserting that sometimes they feel uncomfortable, and only $14,7 \%$ (11,8\% usually $+2,9 \%$ always) percent of students show discomfort speaking it in class. The systematic use of the foreign language and the affective variables provide key information since the creation of a relaxed atmosphere in class is vital to avoid frustration and inhibition when doing activities and tasks, and this will ultimately benefit the improvement of linguistic skills.

Another dimension investigated in the students' questionnaire was the degree of appreciation of the variety of tasks carried out. All the activities were designed to promote interaction and to develop the students' communicative competences. We wanted to detect the general and particular enjoyment of the activities used in class and which of them were preferred. The majority of students usually or always enjoy working with songs $(88,3 \%)$, stories $(97 \%)$, role-plays $(100 \%)$, videos $(97,1 \%)$, games $(100 \%)$, and computers $(100 \%)$. It is noteworthy that there is a substantial difference in the preference for readers, newspapers and magazines. Again, there is a consistent tendency to enjoy working with oral practice rather than with written skills, in this case reading in particular. This is a relevant fact because they are students with low linguistic proficiency and they are likely to perform poorly in this area. 


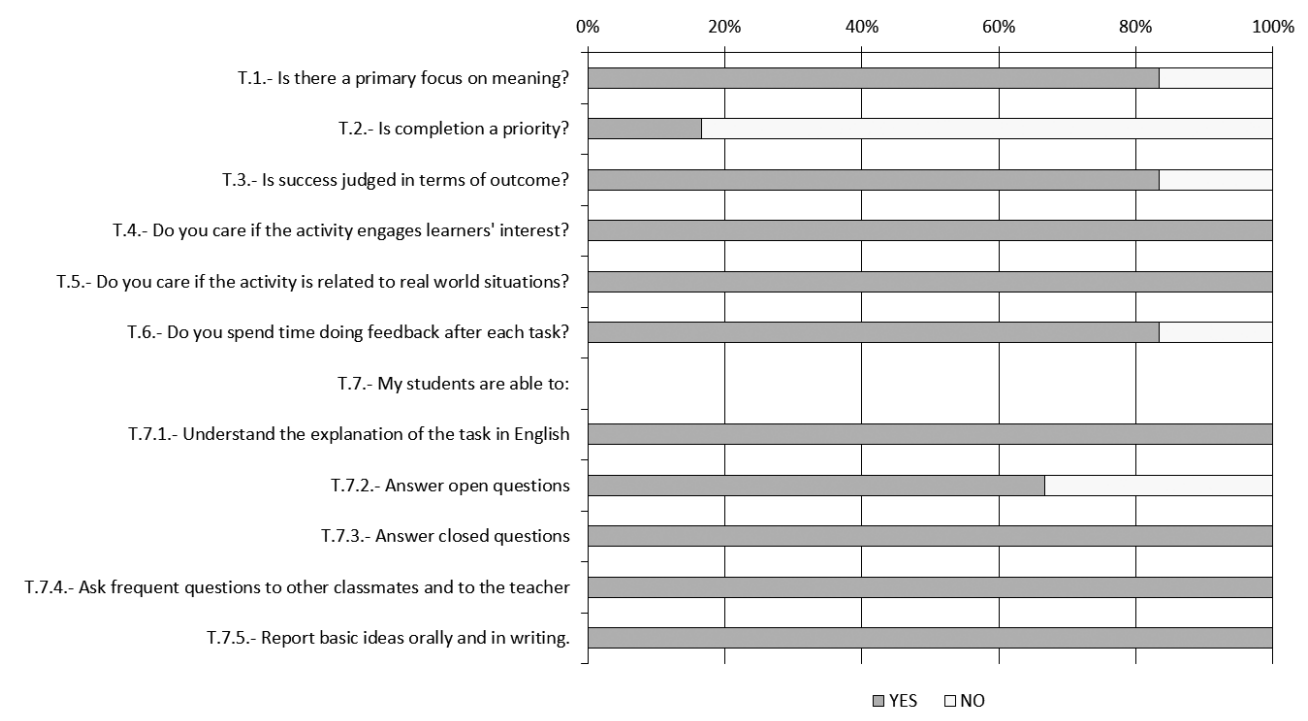

Figure 3: Teachers' perceptions

Figure 3 presents data of two different dimensions, the first one deals with the teacher's own perception of his/her role in the class (questions T1, T2, T3, T4, T5, T6), and the second one focusing on his/her perceptions of the students' performance (T7). With similar percentages most of the teachers consider that meaning is more important than the form when doing tasks $(83 \%)$, they value that the completion of the task is not a priority $(82 \%)$, and they judge that success is not determined by the outcome of the task $(83 \%)$. In short, they seem to be well aware that in task-based learning, the process is as important, or even more, than the product. Almost all the teachers focus on meaning rather than on the grammatical forms, and as a consequence, they carry out tasks which may encourage communicative language and the students' linguistic skills development. Regarding the teachers' usefulness for making tasks interesting and attractive, all the teachers are concerned with engaging the students' interest and about providing tasks related to real world situations. In addition, the majority of teachers $(83 \%)$ spend time giving feedback after each task. Time for feedback reinforces what they have learnt, provides an opportunity to communicate with students, and gives teachers clues about things to improve for future occasions.

As for the second dimension analysed, the teachers' perception of the students' performance, all the teachers report a positive performance on the part of the students. Particularly, students can understand explanations of the tasks with no difficulty, answer closed questions, ask other classmates and the teacher questions frequently, and report basic ideas orally and in writing: all of these features suggest that learners are making use of suitable actions to improve their linguistic skills. All the teachers seek to engage students' interest and try to deal with real situations, with the idea that if students are interested in the task, they are more likely to learn new things. This also involves a relaxed atmosphere where they carry out the task with greater commitment, enthusiasm and motivation, which is beneficial for 
their learning process. In addition, involving students in tasks similar to real situations develops their communicative competence, and by extension, strengthens their linguistic skills. However, the teachers reported their students are not able to answer open ended questions $(33 \%)$, a possible consequence of their limited linguistic proficiency. Results in this specific dimension indicate that students make consistent use of student-teacher interaction and, more importantly, of student-student interaction.

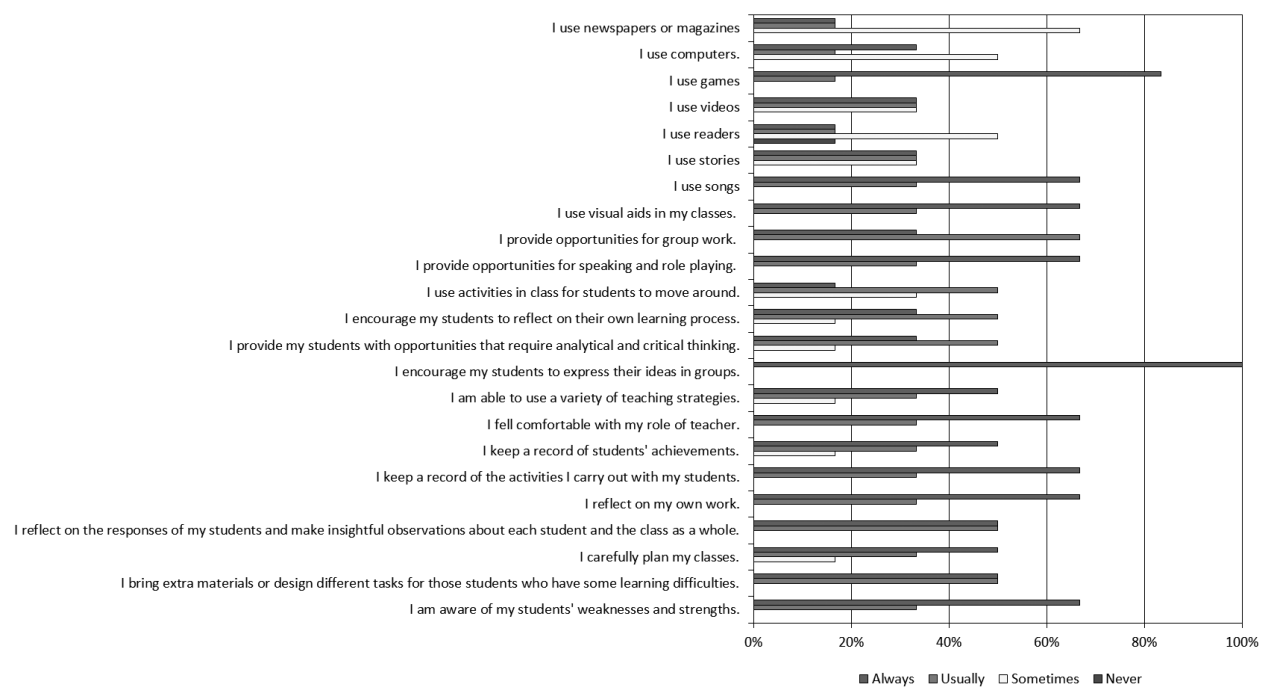

Figure 4: Teachers' practice

Figure 4 introduces data related to the teachers' reflection on their own practice, particularly on the planning of their teaching and their reactions towards the appearance of learning problems. Generally, teachers are aware of their students' weaknesses and strengths (100\%: $33,3 \%$ usually $+66,7 \%$ always), and they bring extra materials or design different tasks for students with some learning difficulties (100\%: 50\% usually $+50 \%$ always). Also, most of them carefully plan their classes (88,5\%: 33,5\% usually $+50 \%$ always), and the majority reflect on their students' responses and on their own work (100\%: 50\% usually + $50 \%$ always; and 100\%: $33,3 \%$ usually $+66,7 \%$ always, respectively). Being aware of the students' weaknesses and strengths enables teachers to design more effective and motivating tasks. Analysis of their own work, and of the students' needs and reactions, helps teachers find ways to make all the students improve their linguistic skills.

In line with the previous analysis, Figure 4 depicts some of the actions taken by teachers to maintain a relaxed and comfortable atmosphere in class, to ensure proper attention to the students' performance, and to promote students' interaction and use of the foreign language. Most of the teachers always keep a record of the tasks carried out in class $(66,7 \%)$, and half of them of their students' achievements (50\%). Keeping a record of the tasks and of the students' achievements allows teachers to measure learners' improvements efficiently. The majority feel comfortable with their role as teacher $(66,7 \%)$, and a large majority $(88,3 \%)$ 
are able to use, 'usually' (33,3\%) and 'always' (50\%), a variety of teaching strategies. Feeling comfortable as a teacher is critical in making students feel secure and relaxed in class, whereas using a variety of strategies leads to effective teaching since this way teachers are more likely to take into account the learners' different needs. One notable result is that $100 \%$ of teachers encourage their students to express and examine their ideas in groups, an action aimed at fostering interaction among the students and which undoubtedly helps to create the best conditions to develop their linguistic skills.

With regard to the provision of opportunities for students to interact and to use the foreign language in a collaborative way, most of the teachers in the study provide opportunities for analytical and critical thinking (83,3\%: 50\% usually $+33,3 \%$ always). This is relevant as practice in critical thinking makes students more precise and specific in noting what is relevant and what is not. As Cottrell (2011:4) claims, critical thinking is closely linked to accuracy because "it is connected to the way learners think and work". Therefore, critical skills imply precision and accuracy in the development of the different steps of a task. With similar figures (83,3\%: $50 \%$ usually $+33,3 \%$ always), teachers report that they encourage their students to reflect on their own learning process. This is also beneficial for students as when they communicate and reflect on what they have learnt, personal and academic achievements arise.

A significant finding is that teachers often use activities for students to move around (66,7\%: $50 \%$ usually $+16,7 \%$ always), and above all, for speaking and role-playing ( $100 \%$ : $33,3 \%$ usually $+66,7 \%$ always) and for group work (100\%: $66,7 \%$ usually $+33,3 \%$ always). Moving around the class, encouraging students to express themselves, role-playing, and working in groups are things that make students use the language for communicative purposes, foster their motivation, and strengthen their linguistic skills. Finally, $100 \%$ of the teachers reported that they use visual aids to support their explanations and to facilitate communication between themselves and the students. Teachers consistently incorporate gestures, mime, and visual aids such as flash cards, pictures, slide-projectors, charts, mind-maps, or drafts.

\section{Conclusion}

The research presented was aimed at investigating to what extent teachers and students feel that the use of task-based learning can favour participation and interaction in a CLIL context where students have low linguistic proficiency. The focus was also on analysing the most widespread strategies adopted by the teachers to promote interaction, on studying students' use of the foreign language, and if this approach could increase students' motivation. On the basis of the collected data, some significant aspects emerge. First of all, the results suggest that teachers and students agree that task-based learning offers the ideal conditions for the development of interaction and cooperative learning, even though the students' linguistic competence is not high (ranging from A1 to A1.2).

Specifically, and related to the first research question, the results of this study support the optimism for the adoption of task-based learning even if the students' linguistic proficiency is not high, corroborating in this context that it encourages them to speak in English when doing a task (Ting, 2010; Meyer, 2010). Consequently, task-based learning contributes to the creation of a cooperative and relaxed learning atmosphere, since students enjoy working with 
and learning new things in class. In addition, students recognized that they prefer to work in pairs/groups, which inevitably leads to greater use of English and, as a consequence, to the development of their linguistic skills. Teachers also report that oral skills develop more than written ones, which at first glance might seem surprising because students generally tend to minimise oral interaction if linguistic abilities are not high. This supports the claim made by Casal (2008) and De Graaf et al. (2007) that cooperative learning may in fact be a powerful strategy to counteract the negative effects of overusing receptive skills in the CLIL classroom.

With regard to the second research question, it can be stated that teachers make use of appropriate techniques and strategies to promote the use of the foreign language, whether individually or in groups. Teachers' own perception of their work is an important factor in the success of CLIL, as teachers are responsible for providing adequate support by scaffolding students' negotiation of meaning (Bonnet, 2012b:182), and scaffolding is necessary to help students structure and accomplish tasks (Meyer, 2010:15). Teachers deploy an array of activities to attract and maintain their attention, and what is even more important, to accommodate the different learning styles of the students. They carefully plan their lessons in order to provide students with an ideal scenario, reflect on their teaching practice and on the students' performance in an attempt to polish and improve their teaching. The teacher's role largely consists of monitoring and guiding the students, allowing them to think and solve the tasks by themselves, in line with the guidelines for the promotion of interaction suggested by scholars and researchers (Mackey, 1999; Della Puppa, 2008).

Concerning the third research question, the results show that students feel motivated to participate and interact, and that they do not experience uncomfortable or negative emotions during the fulfilment of tasks. Contrary to the assumption that motivation and self-esteem may be affected negatively in CLIL (Bruton, 2011, 2013), results show that participation of the students is in fact stimulated and they feel more motivated and interested in using the foreign language. This fact is particularly relevant because in this study the students were in their initial stages of the CLIL instruction, and it corresponds to the findings in Brevick and Moe (2012) who detected that during the first stages of CLIL, students' attitude is of acceptance and enthusiasm. In theory, a low linguistic proficiency may limit the possibilities of communication, and a limited knowledge of the language may hinder the access to content material. However, in line with the conclusions laid out by Seikkula-Leino (2007), Breton (2008), Hunt (2011), Lasagabaster (2011), Poisel (2012) and Coonan (2012), in this particular context with these students, these negative effects were not found: students felt confident and willing to participate, and they found learning useful and enjoyable. Furthermore, even though their linguistic level is not high, they display a genuine interest in working in groups and in using the foreign language as much as possible, which makes provision for suitable conditions to develop their linguistic skills appropriately.

It is important to note that this research evaluates the perceptions of teachers and students regarding task-based learning in CLIL, but not the students' performance. Further investigations would be necessary to provide "evidence of the language outcomes and of the subject matter achievements" (Zydatib, 2012:28), particularly resulting from the combination of task-based learning and CLIL with this type of students, with other kinds of learners, and in different contexts. 


\section{REFERENCES}

Arnold, J. (2011). "El dominio afectivo en la enseñanza bilingue", in S. Casal (ed.), Implicaciones de la enseñanza bilingüe en centros educativos. Sevilla: Aljibe, 37-48.

Baetens-Beardsmore, H. (2001). "Foreword: The past decade and the next millennium", in D. Marsh, A. Maljers and A. Hartiala (eds.), Profiling European CLIL Classrooms. (UNICOM: University of Jyväskylä \& European Platform for Dutch Education, 10-119.

Berton, G. (2008). "Tasks, learning activities and oral production skills in CLIL classrooms", in M. Coonan (ed.), CLIL e l'Appredimento delle Lingue. Le Sfide del Nuovo Ambiente di Apprendimento. Venezia: University Ca' Foscari, Venezia, 143-151.

Bonnet, A. (2012a). "Towards an evidence base for CLIL: how to integrate qualitative and quantitative as well as process, product and participant perspectives in CLIL research", in International CLIL Research Journal, 1, 4: 66-78.

Bonnet. A. (2012b). "Language, content and interaction: how to make CLIL classroom work", in D. Marsh and O. Meyer (eds.), Quality Interfaces: Examining Evidence \& Exploring Solutions in CLIL. Eichstätt: Eichstätt Academic Press, 172-189.

Brevik, M. and Moe, E. (2012). "Effects of CLIL teaching on language outcomes", in D. Tsagari and I. Csépes (eds.), Collaboration in Language Testing and Assessment. Berlin: Peter Lang, 213-227.

Bruton, A. (2011). "Is CLIL so beneficial, or just selective? Re-evaluating some of the research", in System, 39: 523-532.

Bruton, A. (2013). "CLIL: Some of the reasons why ... and why not", in System, 41: 587-597.

Carless, D. (2004). "Issues in teachers' reinterpretation of a task-based innovation in primary schools", in TESOL Quarterly, 38, 4: 639-662.

Casal, S. (2008). "Cooperative learning in CLIL contexts: ways to improve students' competences in the foreign language classroom". Paper presented in the IAIE Conference Cooperative Learning in Multicultural Societies: Critical Reflections. Turin. Retrieved from: http:// soniacasal.wordpress.com/2008/10/18/cooperative-learning-in-clil-contexts-ways-to-improvestudents-competences-in-the-foreign-language-classroom/

Candlin, C.N. and Murphy, D.F. (eds.)(1987). Language Learning Tasks. Englewood Cliffs, NJ: Prentice-Hall International.

Cendoya, A. and Di Bin, M. (2010). "A CLIL experience based on the use of tasks and different genre types", in Latin American Journal of Content \& Language Integrated Learning, 3, 1: 11-17.

Cenoz, J., F. Genesee, F. and Gorter, D. (2013). "Critical Analysis of CLIL: Taking Stock and Looking Forward”, in Applied Linguistics (advance access) 1-21.http://applij.oxofrdjournals.org/

Coonan, C.M. (2012). "Affect and motivation in CLIL", in D. Marsh and O. Meyer (eds.), Quality Interfaces: Examining Evidence \& Exploring Solutions in CLIL. Eichstätt: Eichstätt Academic Press, 52-65.

Cottrell, S. (2011). Critical Thinking Skills. Developing Effective Analysis and Argument. London: Palgrave Macmillan.

Council of Europe (2001). Common European Framework of Reference for Languages: Learning, Teaching, and Assessment. Cambridge: Cambridge University Press.

Coyle, D. (2013). "Listening to learners: an investigation into 'successful learning' across CLIL contexts", in International Journal of Bilingual Education and Bilingualism, 16, 3: 244-266.

Coyle, D., Hood, P. and Marsh, D. (2010). CLIL: Content and Language Integrated Learning. Cambridge University Press. 
D’Angelo, L. and García Pascual, E. (2012). "The personal and professional profile of the CLIL subject teacher: a research study", in D. Marsh and O. Meyer (eds.), Quality Interfaces: Examining Evidence \& Exploring Solutions in CLIL. Eichstaett: Eichstaett Academic Press, 66-77.

Dalton-Puffer, D., Nikula, T. and Smit, U. (2010). "Language use and language learning in CLIL: current findings and contentious issues", in C. Dalton-Puffer, T. Nikula and U. Smit (eds.), Language Use and Language Learning in CLIL. Amsterdan: John Benjamins, 279-291.

De Graaf, R., Koopman, G.J., Anikina, Y. and Westhoff, G. (2007). "An observation tool for effective L2 pedagogy in Content and Language Integrated Learning (CLIL)". The International Journal of Bilingual Education and Bilingualism, 10, 5: 603-624.

Dörnyei, Z. (1997). "Psychological processes in cooperative language learning: group dynamics and motivation". The Modern Language Journal, 81, 4, 482-493.

Ellis, R. (2003). Task-based Language Learning and Teaching. Oxford. Oxford University Press.

Escobar, C. and Sánchez, A. (2009). "Language learning through tasks in a Content and Language Integrated Learning (CLIL) science classroom", in Porta Linguarum, 11: 65-83.

Eurydice (2006). Content and Language Integrated Learning (CLIL) at School in Europe. Eurydice: Brussels.

García, O. (2009). Bilingual Education in the 21st Century. Hoboken, NJ: Wiley-Blackwell.

Guazzieri, A.V. (2008). "Oral interaction in CLIL student-led cooperative group work", in M. Coonan (ed.), CLIL e l'Appredimento delle Lingue. Le Sfide del Nuovo Ambiente di Apprendimento. Venezia: University Ca' Foscari, Venezia, 79-103.

Hunt, M. (2011). "Learners' perceptions of their experience of learning subject content through a foreign language", in Educational Review, 6, 3: 365-378.

Lasagabaster, D. (2008). "Foreign language competence in content and language integrated courses", in The Open Applied Linguistics Journal, 1: 31-42.

Lasagabaster, D. (2011). "English achievement and student motivation in CLIL and EFL settings", in Innovation in Language Learning and Teaching, 5: 3-18.

Llinares, A., Morton, T. and Whitttaker, R. (2012). The Roles of Languages in CLIL. Cambridge: Cambridge University Press.

Long, M.H. (1996)." The role of the linguistic environment in second language acquisition", in W.C. Ritchie and T.K. Bhatia (eds.), Handbook of second language acquisition. New York: Academic Press, 413-468.

Lorenzo, F., S. Casal, and Moore, P. (2009). "The effects of content and language integrated learning in European education: key findings from the Andalusian bilingual sections evaluation project", in Applied Linguistics, 31, 3: 418-442.

Mackey, A. (1999). "Input, interaction, and second language development: en empirical study in question formation in ESL", in Studies in Second Language Acquisition, 21: 557-587.

Marsh, D. (2000). Using Languages to Learn and Learning to Use Languages. Jyväskylä: University of Jyväskylä.

Marsh, D. (ed.)(2002). CLIL/EMILE-The European Dimension: Actions, Trends and Foresight Potential, Public Services Contract DG EAC. Strasbourg: European Commission.

Marsh, D. (2007). "Language awareness and CLIL", in J. Cenoz and N.H. Hornberger (eds.), Encyclopedia of Language and Education. Knowledge about Language, $2^{\text {nd }}$. edition, Volume 6. New York: Springer Science and Business Media LLC, 233-246.

Marsh, D. (2013). The CLIL Trajectory: Educational Innovation for the 21st Century iGeneration. Córdoba: University of Cordoba Academic Press. 
Mehisto, P. (2012). "Criteria for producing CLIL learning material", in Encuentro, 21: 15-33. Méndez García, M.C. (2013). "The intercultural turn brought about by the implementation of CLIL programmes in Spanish monolingual areas: a case Study of Andalusian primary and secondary schools", in The Language Learning Journal 41, 5: 268-283.

Meyer, O. (2010). "Towards quality-CLIL: successful planning and teaching strategies", in Puls, 33: 11-29.

Mondt, K., Struys, E., Van den Noort, M., Balériaux, D., Metens, T., Paquier, P., Van de Craen, P., Bosch, M. and Denolin, V. (2011). "Neural differences in bilingual children's arithmetic processing depending on language of instruction", in Mind, Brain, and Education, 5, 2: 79-88.

Nunan D. (1989). Designing Tasks for the Communicative Classroom. Cambridge: Cambridge University Press.

Pastor, M.R. (2011). "CLIL and cooperative learning", in Encuentro, 20: 109-118.

Pavón, V. and Ellison, M. (2013). "Examining teacher roles and competences in content and language integrated learning (CLIL)", in Linguarum Arena, 4: 65-78.

Pena, C. and Porto, M.D. (2008). "Teacher beliefs in a CLIL education project", in Porta Linguarum, 10: 151-161.

Pérez, I. (2012). "Los beneficios del enfoque por tareas aplicado al aprendizaje integrado de contenidos", in R. Breeze, F. Jiménez, C. Llamas, C. Martínez and C. Tabernero (eds.), Teaching Approaches to CLIL / Propuestas Docentes en AICLE. Pamplona: Servicio de Publicaciones de la Universidad de Navarra, 265-272.

Perez Cañado, M.L. (2012). "CLIL research in Europe: past, present, and future", in International Journal of Bilingual Education and Bilingualism, 15, 3: 315-341.

Poisel. E. (2012). "Competence development through task-based learning", in D. Marsh and O. Meyer (eds.), Quality Interfaces: Examining Evidence \& Exploring Solutions in CLIL. Eichstätt: Eichstätt Academic Press, 251-263.

Puppa, F. della. (2008). "La partecipazione orale in italiano L2: incremento dell'inclusione attraverso il Cooperative Learning", in M. Coonan (ed.), CLIL e l'Appredimento delle Lingue. Le Sfide del Nuovo Ambiente di Apprendimento Venezia: University Ca' Foscari, Venezia., 167-176.

Ryba, R. (1992). "Towards a European dimension in education: intention and reality in European community policy and practice", in Comparative Education Review, 36, 1 (Special Issue on Education in a Changing Europe): 10-24.

Seikkula-Leino, J. (2007). "CLIL learning: achievement levels and affective factors", in Language and Education, 21: 328-341.

Tardieu, C. and Doltisky, M. (2012). "Integrating the task-based approach to CLIL teaching", in L. de Dios (coord.), Teaching and Learning English Through Bilingual Education. Cambridge: Cambridge Scholars Publishing, 3-35.

Ting, T. (2010). "CLIL appeals to how the brain likes its information: examples from CLIL-(neuro) science", in International CLIL Research Journal, 3: 1-18.

Toscano, C.M. (2011). "Adecuación del tipo de tarea al desarrollo de aprendizaje del alumnado dentro de la enseñanza plurilingüe", in S. Casal (ed.), Implicaciones de la enseñanza bilingüe en centros educativos. Sevilla: Aljibe, 137-153.

Van de Branden, K. (2006). Task-based Language Education. Cambridge University Press.

Viebrock, B. (2012). "The situation in the CLIL classroom is quite different -or is it? teachers' mindsets, methodological competences and teaching habits", in D. Marsh and O. Meyer 
(eds.), Quality Interfaces: Examining Evidence \& Exploring Solutions in CLIL. Eichstaett: Eichstaett Academic Press, 78-90

Willis, J. (1996). A Framework for Task-based Learning. London: Longman.

Willis, D. and Willis, J. (2007). Doing Task-based Teaching. Oxford: Oxford University Press.

Wolff, D. (2012). "The European Framework for CLIL teacher education", in Synergies, 8: 105-116.

Zydatib, W. (2012). "Linguistic thresholds in the CLIL classroom: the Threshold Hypothesis revisited", in International CLIL Research Journal, 1, 4: 16-28. 
Víctor Pavón, Marta Prieto and Fco. Javier Ávila $\quad$ Perceptions of Teachers and Students...

\section{APPENDICES}

\section{APPENDIX 1 \\ SURVEY FOR STUDENTS}

For each of the statements below, give yourself a score from 1 to 4 according to the following scale.

$$
1=\text { Never; } 2 \text { = Sometimes; } 3 \text { = Usually; } 4 \text { = Always }
$$

$\begin{array}{llllll}\text { I complete the assigned tasks in class. } & 1 & 2 & 3 & 4\end{array}$

$\begin{array}{llllll}\text { I do my homework. } & 1 & 2 & 3 & 4\end{array}$

$\begin{array}{llllll}\text { I prefer to do written tasks. } & 1 & 2 & 3 & 4\end{array}$

$\begin{array}{llllll}\text { I prefer to do oral tasks. } & 1 & 2 & 3 & 4\end{array}$

$\begin{array}{llllll}\text { I participate in the activities and games. } & 1 & 2 & 3 & 4\end{array}$

$\begin{array}{llllll}\text { I like working in pairs and groups. } & 1 & 2 & 3 & 4\end{array}$

$\begin{array}{llllll}\text { I prefer to work individually. } & 1 & 2 & 3 & 4\end{array}$

I enjoy being in class. $\quad \begin{array}{lllll}1 & 2 & 3 & 4\end{array}$

I like learning new things. $\quad \begin{array}{lllll}1 & 2 & 3 & 4\end{array}$

I speak in English in class. $\quad \begin{array}{llll}1 & 2 & 3 & 4\end{array}$

I am embarrassed to speak in class. $\quad \begin{array}{llllll} & 1 & 2 & 3 & 4\end{array}$

$\begin{array}{llllll}\text { I listen to my classmates when they speak. } & 1 & 2 & 3 & 4\end{array}$

I like working with:

\begin{tabular}{|lllll|}
\hline - Songs. & 1 & 2 & 3 & 4 \\
\hline - Stories. & 1 & 2 & 3 & 4 \\
\hline - Role-plays. & 1 & 2 & 3 & 4 \\
\hline - Videos. & 1 & 2 & 3 & 4 \\
\hline - Games. & 1 & 2 & 3 & 4 \\
\hline - Readers. & 1 & 2 & 3 & 4 \\
\hline - Computers. & 1 & 2 & 3 & 4 \\
\hline - Newspapers and magazines. & 1 & 2 & 3 & 4 \\
\hline - Other: & 1 & 2 & 3 & 4 \\
\hline
\end{tabular}




\section{APPENDIX 2 \\ SURVEY FOR TEACHERS}

Give your opinion about the following questions.

When students are doing a task, what do you think is the role of the teacher?

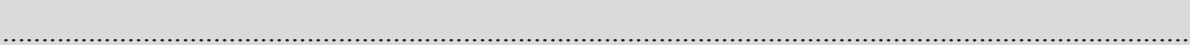

What, in your opinion, are the strengths of the Task-based approach?

Is there anything you think could be improved? Aids, further counselling, etc.

When doing a task, is there an outcome? Which one?

For each of the questions below answer 'yes' or 'no' depending on your usual teaching methodology.

\begin{tabular}{|lcc|}
\hline Is there a primary focus on meaning? & Yes & No \\
\hline Is completion a priority? & Yes & No \\
\hline Is success judged in terms of outcome? & Yes & No \\
\hline Do you care if the activity engages learners' interest? & Yes & No \\
\hline Do you care if the activity is related to real world situations? & Yes & No \\
\hline $\begin{array}{l}\text { Do you spend time doing feedback after each task? } \\
\text { My students are able to: }\end{array}$ & Yes & No \\
\hline -Understand the explanation of the task in English & Yes & No \\
\hline Answer open questions & Yes & No \\
\hline Answer closed questions & Yes & No \\
• Ask frequent questions to other classmates and to the teacher & Yes & No \\
\hline Report basic ideas orally and in writing. & Yes & No
\end{tabular}


For each of the statements below, give yourself a score from 1 to 4 according to the following scale.

$$
1=\text { Never; } 2 \text { = Sometimes; } 3 \text { = Usually; } 4 \text { =Always }
$$

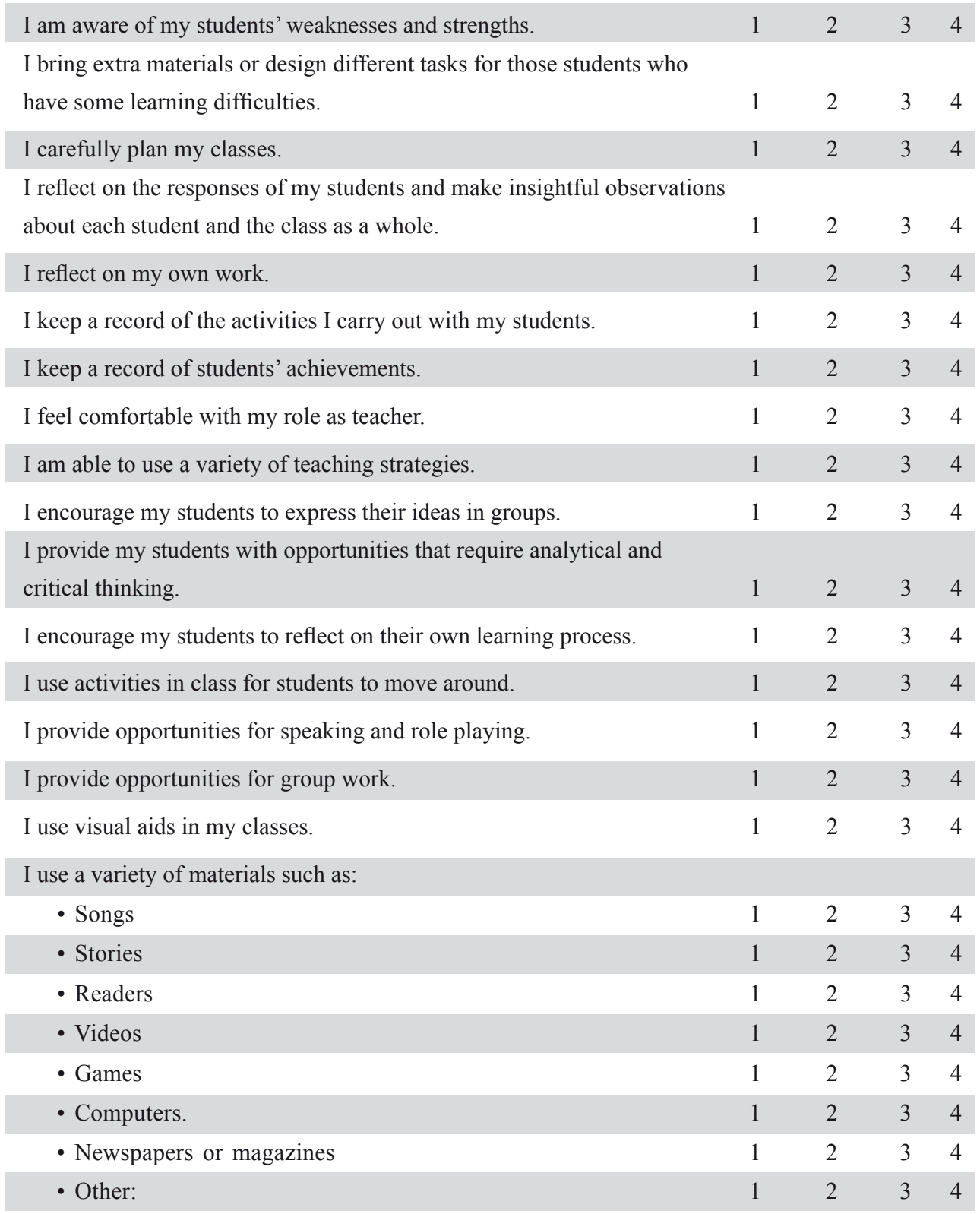

